\title{
Welcome to the Future of Homo Oeconomicus
}

\author{
Manfred J. Holler ${ }^{1}$ - Martin Kocher ${ }^{2}$. \\ Katri K. Sieberg ${ }^{3}$
}

(C) Springer International Publishing Switzerland 2016

Homo Oeconomicus (HOEC) started life in 1983 as a German language occasional series concerned with various aspects of the theoretical and behavioral concept of homo economicus and its application in economics, philosophy, political science, and sociology. In 1995 it became a quarterly journal and in 1998 was fully internationalized with articles being exclusively in English. Since then Homo Oeconomicus has become an outlet for researchers working in the field of political economy, and a huge number of important papers have been published in the journal.

From 2016 onward, Homo Oeconomicus is published by Springer. The journal will benefit from the modern technology and large distribution of an international publisher. We are proud to present the first issue of Homo Oeconomicus after its relaunch in early 2016.

Homo Oeconomicus is an international peer-reviewed journal devoted to the study of classical and neo-classical economics, public choice, collective decisionmaking, game theory, behavioral economics, experimental economics, law \& economics, and philosophical aspects of economics. The journal has traditionally covered a variety of approaches to economic behavior. The journal's new focus has been expanded to explore the interrelationship of behavior and institutions. More specifically, future articles in Homo Oeconomicus will have a focus on research questions related to human decision-making and institutions and the relationship between the two. The journal also seeks research that applies a high degree of interdisciplinarity. In particular, articles that make use of insights that result from

\footnotetext{
Manfred J. Holler

manfred.holler@wiso.uni-hamburg.de

1 University of Hamburg, Hamburg, Germany

2 University of Munich, Munich, Germany

3 University of Tampere, Tampere, Finland
} 
philosophy, psychology, game theory, sociology, history of thought, history, and law and economics are welcome.

Homo Oeconomicus publishes theoretical and empirical/experimental work in the social sciences. It focuses on the rules, norms, regulations, and constraints that affect economic and social decision making, and it accepts both views of humans as decision makers: rational/egoistic and boundedly rational/non-egoistic. The interrelationship of issues and results from behavioral and institutional economics is a subject in strong need of further research. There is also a need for results of this research to be organized and made accessible in an adequate journal. This is the aim of Homo Oeconomicus.

Another strength of Homo Oeconomicus is that, by the nature of its interdisciplinary focus, it takes results of neighboring sciences seriously when they contribute to the understanding of the behavioral and institutional dimensions in individual and social decision making. This broader perspective provides a valuable resource that cannot be found in journals with a focus on only one discipline.

Homo Oeconomicus should be of special interest to readers who are trying to discover novel aspects of human decision-making and institutional design by expanding their research into areas that are not covered by most mainstream journals of economics.

An important feature of Homo Oeconomicus lies in the constructive approach to publication. While operating a rigorous review procedure, we work closely with our authors to make sure that publishing in Homo Oeconomicus is not an adversarial but a cooperative experience.

This double issue of Homo Oeconomicus 33(1-2) features a provocative keynote by Nobel Laureate Edmund Phelps ("What Is Wrong with the West's Economies?") and eight comments by outstanding scholars who responded to the challenges presented in Phelps' note. The reaction was overwhelming. This allows us to continue the discussion with more comments in the upcoming issues of HOEC.

The double issue also presents seven regular papers:

- Francesc Carreras/Guillermo Owen: Pure Bargaining Problems with a Coalition Structure

- Jean-François Laslier: Heuristic Voting Under the Alternative Vote: The Efficiency of "Sour Grapes" Behavior

- László Kóczy: Power Indices When Players Can Commit to Reject Coalitions

- Max Albert/Andreas Hildenbrand: Industrial Organization and Experimental Economics: How to Learn from Laboratory Experiments

- Berno Buechel/Jan F. Klein: Restrictions in Spatial Competition: The Effects on Firms and Consumers

- Mario Ferrero: Jesus and the Ratchet

- Marie Luise Funke/Helena Xiang Li/Horst Löchel: The High Profitability of Big Chinese State-Owned Banks and China's Growth Model

To close the circle, the topic of the latter directly relates to Phelps' keynote and the responses published in this number of the journal. All in all, this issue contains a very interesting selection of topics, analytical methods and results that we expect to find in HOEC also in the future. We invite all researchers working in the fields covered by HOEC to submit their papers and thus to contribute to the exciting new era of Homo Oeconomicus. 